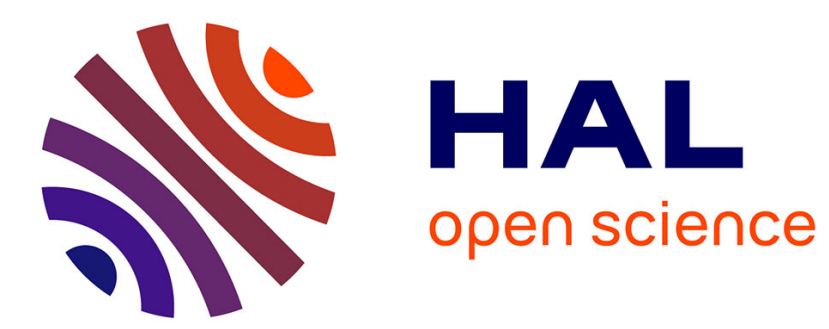

\title{
Itinerant antiferromagnetism of TiBe2
}

\author{
B.T. Matthias, A.L. Giorgi, V.O. Struebing, J.L. Smith
}

\section{To cite this version:}

B.T. Matthias, A.L. Giorgi, V.O. Struebing, J.L. Smith. Itinerant antiferromagnetism of TiBe2. Journal de Physique Lettres, 1978, 39 (22), pp.441-442. 10.1051/jphyslet:019780039022044100 . jpa00231538

\section{HAL Id: jpa-00231538 https://hal.science/jpa-00231538}

Submitted on 1 Jan 1978

HAL is a multi-disciplinary open access archive for the deposit and dissemination of scientific research documents, whether they are published or not. The documents may come from teaching and research institutions in France or abroad, or from public or private research centers.
L'archive ouverte pluridisciplinaire HAL, est destinée au dépôt et à la diffusion de documents scientifiques de niveau recherche, publiés ou non, émanant des établissements d'enseignement et de recherche français ou étrangers, des laboratoires publics ou privés. 


\section{ITINERANT ANTIFERROMAGNETISM OF $\operatorname{TiBe}_{2}\left({ }^{*}\right)\left({ }^{* *}\right)$}

\section{B. T. MATTHIAS $\left({ }^{* * *}\right)$, A. L. GIORGI, V. O. STRUEBING and J. L. SMITH}

Los Alamos Scientific Laboratory, University of California Los Alamos, New Mexico 87545, U.S.A.

(Reçu le 23 août 1978, accepté le 27 septembre 1978)

Résumé. - $\mathrm{TiBe}_{2}$ est le premier antiferromagnétique itinérant.

Abstract. - $\mathrm{TiBe}_{2}$ is the first itinerant antiferromagnet.

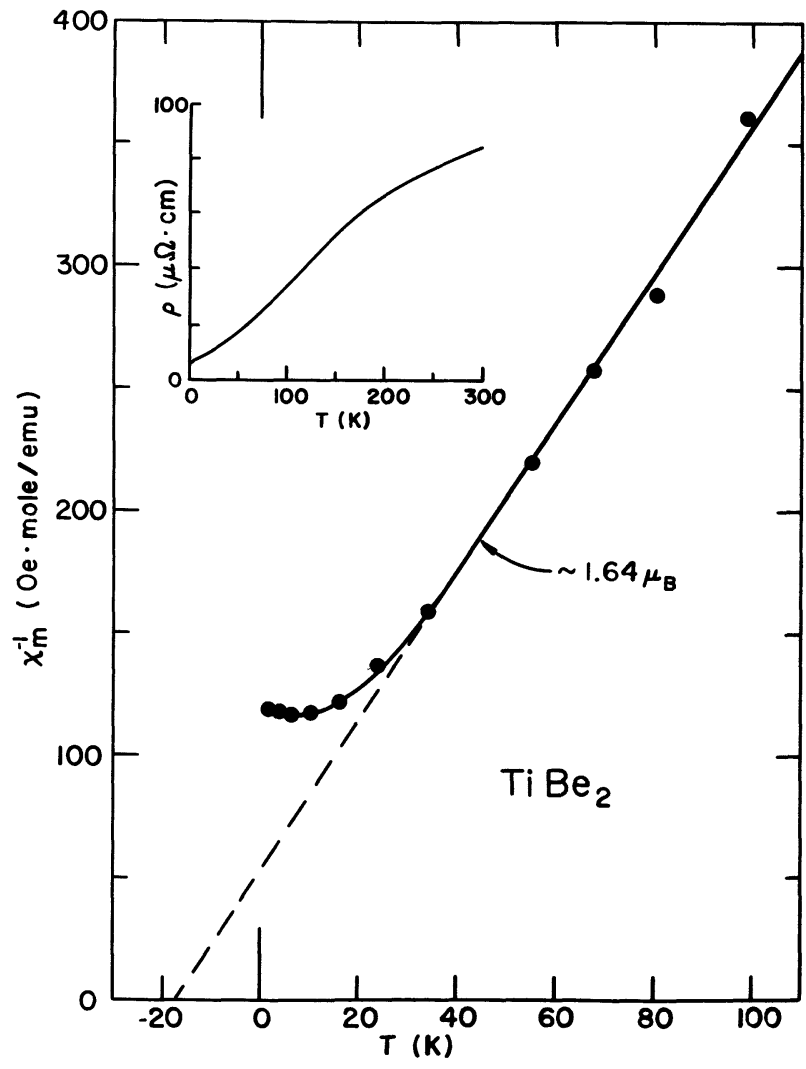

FIG. 1. - Inverse magnetic susceptibility and electrical resistivity of $\mathrm{TiBe}_{2}$ as a function of temperature.

(*) Work performed under the auspices of the U.S. Department of Energy.

$\left.{ }^{(* *}\right)$ This paper has been presented at the LT 15 Conference as a post deadline paper.

$\left({ }^{* * *}\right)$ Department of Physics, University of California, San Diego, La Jolla, California 92093 and Bell Laboratories, Murray Hill, New Jersey 07974. Research in La Jolla sponsored by NSF/DMR77-08469.
Itinerant electron ferro- or antiferromagnetism in metallic compounds can only be taken for certain, if neither of the elements is known ever to have a local moment in its metallic state. Until now, of all known materials only $\mathrm{Sc}_{3} \mathrm{In}$ [1] and $\mathrm{ZrZn}_{2}$ [2] fulfilled this criterion. On the basis of a recent theoretical analysis [3] it seemed quite probable that $\mathrm{TiBe}_{2}$, crystallizing in a cubic Laves phase would also be an itinerant magnet. We have now verified this expectation and thus found a third, truly itinerant magnet. In figure 1 the inverse magnetic susceptibility shows $\mathrm{TiBe}_{2}$ to be an antiferromagnet with its Néel point near $10 \mathrm{~K}$ and a magnetic moment of $1.64 \mu_{\mathrm{B}}$. The metallic nature is obvious by the $\mathrm{Ti}-\mathrm{Ti}$ distances,

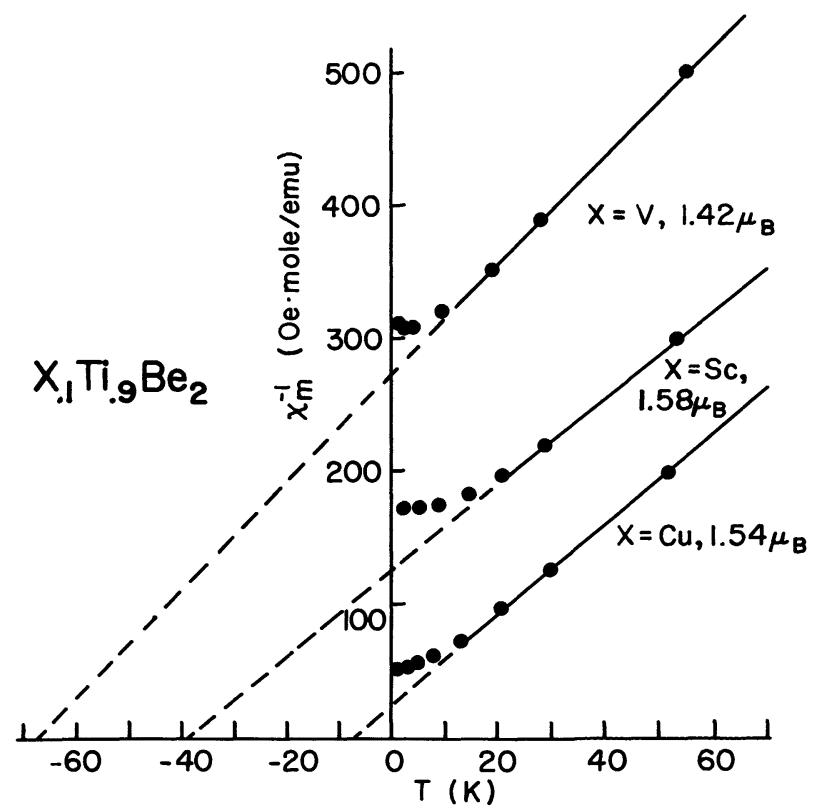

FIG. 2. - Effect of replacement of 10 at. \% Ti by other elements. $\mathrm{Zr}$ and $\mathrm{Nb}$ essentially coincide with $\mathrm{Sc}$. 
which are identical to those of the pure element as well as through its $R v s$. $T$ behaviour as shown in the insert (Fig. 1). The lattice parameter of the material is $a_{0}=6.4532 \pm 4 \AA$.

Both elements in $\mathrm{TiBe}_{2}$ are superconductors by themselves and the resemblance to $\mathrm{ZrZn}_{2}$ is unmistakable. However, while $\mathrm{ZrZn}_{2}$ is a weak ferromagnet with a Curie point near $30 \mathrm{~K}$, there is as expected from figure 1 , no evidence for a spontaneous magne- tization in $\mathrm{TiBe}_{2}$ below its critical temperature. We have not found any superconductivity above $20 \mathrm{mK}$. As had been anticipated [3], titanium is essential for the magnetism and any dilution with neighbouring elements will invariably reduce the magnetic moment, see figure 2 . With this discovery of itinerant antiferromagnetism in $\mathrm{TiBe}_{2}$, based on the theory of $\mathrm{ZrZn}_{2}$, it may well be possible now to predict further itinerant electron magnets.

\section{References}

[1] Matthias, B. T., Clogston, A. M., Williams, H. J., CorenzWIT, E. and SHERWOOD, R. C., Phys. Rev. Lett. 7 (1961) 7.

[2] Matthias, B. T. and Bozorth, R. M., Phys. Rev. 109 (1958) 604.

[3] EnZ, C. P. and Matthias, B. T., Science, in press. 